THE EARLY MODERN WORLD 


\title{
THE POPE'S HOUSEHOLD AND COURT IN THE EARLY MODERN AGE
}

\author{
Maria Antonietta Visceglia
}

Traditionally, the international historiography of the papal court in the Modern Age has concentrated on the origins and development of the curial bureaucracy, ${ }^{1}$ and on the relationship between this bureaucracy and the Italian aristocracy. This practice was in line with the general debate about the rise of the modern state-of which the Ecclesiastical State could be considered an early, original model. ${ }^{2}$ Studies on the figure of the cardinal-nephew-the secretary of state ${ }^{3}$-and on pontifical diplomacy added a lively field of research still fitting into the above-mentioned debate. ${ }^{4}$

${ }^{1}$ Peter Partner, The Pope's Men: the Papal Civil Service in the Renaissance (Oxford 1990).

2 Paolo Prodi, Il sovrano pontefice. Un corpo e due anime: la monarchia papale nella prima età moderna (Bologna 1982) translated Susan Haskins, The Papal Prince, One Body and Two Souls: The Papal Monarchy in Early Modern Europe (Cambridge 1987). The bibliography on the themes of bureaucracy and Italian aristocracy of the papal state in the modern era is extensive. These research themes were established at the end of the 1990s with the reviews of Marco Pellegrini, 'Corte di Roma e aristocrazie italiane in età moderna. Per una lettura storico-sociale della curia romana', in: Rivista di storia e letteratura religiosa XXX (1994) pp. 543-602; Maria Antonietta Visceglia, 'Burocrazia, mobilità sociale e patronage alla corte di Roma tra Cinque e Seicento. Alcuni aspetti del recente dibattito storiografico e prospettive di ricerca', in: Roma moderna e contemporanea. Rivista interdisciplinare di storia III, 1 (1995). I will point out among the most recent contributions: Armand Jamme and Olivier Poncet, Offices et Papauté. Charges, Hommes, Destins (XIVe-XVII siècle) (Rome 2005); Antonio Menniti Ippolito, Il governo dei papi nell'età moderna. Carriere, gerarchie, organizzazione curiale (Rome 2007).

${ }^{3}$ Madeleine Laurain-Portemer, 'Absolutisme et Népotisme. La Surintendance de L'État Ecclésiastique', Bibliothèque de l'École des Chartes CXXXI (1973), and most recently Antonio Menniti Ippolito, Il tramonto della Curia nepotista. Papi, nipoti e burocrazia curiale tra XV e XVII secolo (Rome 1999).

${ }^{4}$ Georg Lutz, 'Le ricerche internazionali sulle nunziature e l'edizioni delle istruzioni generali di Clemente VIII', in: L'Archivio Segreto Vaticano e le ricerche storiche, Paolo Vian, ed. (Rome 1983); Georg Lutz, ed., Das Papsttum, die Christenheit und die Staaten Europas, 1592-1605: Forschungen zu den Hauptinstruktionen Clemens' VIII (Tübingen 1994); Alexander Koller, ed., Kurie und Politik; Stand und Perspektiven der Nuntiaturberichtsforschung (Tübingen 1998). 
This institutional approach has since become more elaborate and been enriched by German ${ }^{5}$ and Italian ${ }^{6}$ research on the social history of the Roman Curia. These later studies have stressed the courtly dynamic that contributed to the selection of papal personnel, highlighting the role of kinship within the familia of the reigning pontiff and among the cardinal families, the meaning of friendship as a system of reciprocity, and the practice of patronage leading to groups of clients. While the theme of the pontiff's household can be seen as part of this subject, unlike the cardinal families, it has not to date been the object of specific research. ${ }^{7}$

In contrast, at the European level there have been many studies on the relationship between Household and Court in the Medieval and Modern ages, which have opened up new questions and reflections about the relationship between the sovereign's private entourage and the bureaucratic structures of the State. ${ }^{8}$ At all European courts the

${ }^{5}$ I restrict myself to citing Wolfgang Reinhard, Freunde und Kreaturen. "Verflechtung" als Konzept zur Erforschung Historischer Führungsgruppen. Römische Oligarchie um 1600 (Munich 1979); Wolfgang Reinhard, 'Amici e creature. Micropolitica della curia romana nel XVII secolo', Dimensioni e problemi della ricerca storica 2 (2001) p. 61; Irene Fosi Polverini, 'Amici, creature, parenti: la corte romana osservata da storici tedeschi', Dimensioni e problemi della ricerca storica 2 (2001); Julia Zunckel and Wolfgang Reinhard, eds., Römische Mikropolitik unter Papst Paul V. Borghese (1605-1621), zwischen Spanien, Neapel, Mailand und Genua (Tübingen 2004).

${ }^{6}$ Renata Ago, Carriere e clientele nella Roma barocca (Rome 1990); Irene Polverini Fosi, All'ombra dei Barberini: fedeltà e servizio nella Roma barocca (Rome 1997); Gianvittorio Signorotto and Maria Antonietta Visceglia, eds., La corte di Roma fra Cinque e Seicento "Teatro" della politica europea (Rome 1998).

7 Pierre Hurtubise, 'Familiarité et fidelité à Rome au XVI' siècle: les 'familles' des cardinaux Giovanni, Bernardo et Antonio Maria Salvati', in: Hommage à Roland Mousnier. Clientèles et fidelité en Europe à l'époque moderne, Y. Durand, ed. (Paris 1981) p. 342. On the cardinal "family", refer to, Pierre Hurtubise, "La "familia" del cardinale Giovanni Salviati (1517-1553)', in: "Familia" del Principe e famiglia aristocratica, Cesare Mozzarelli, ed. (Rome 1988) pp. 589-609; Lucinda Byatt, 'Aspetti giuridici e finanziari di una "familia" cardinalizia del XVI secolo: un progetto di ricerca', in: "Familia" del Principe, Cesare Mozzarelli, ed. (Rome 1988) pp. 611-627; Gigliola Fragnito, "Parenti" e "familiari" nelle corti cardinalizie del Rinascimento', in: "Familia" del Principe, Cesare Mozzarelli, ed. (Rome 1988) pp. 565-587; Gigliola Fragnito, 'Le corti cardinalizie nella Roma del Cinquecento', Rivista storica italiana, CVI (1994) pp. 5-41.

${ }^{8}$ From the rich bibliography on this theme, I restrict myself to citing the contributions that I have directly utilized in these pages: John Adamson, The Princely Courts of Europe: Ritual, Politics and Culture under the Ancien Régime 1500-1750 (London 1999); Jacqueline Boucher, 'L'évolution de la Maison du Roi des derniers Valois aux premiers Bourbons', XVII ${ }^{e}$ siècle, XXXIV (1982) pp. 359-379; Miguel Angel Ladero Quesada, 'Casa y Corte. L'Hôtel du roi et la Cour comme institutions économiques au temps de Rois Catholiques', in: La cour comme institution économique, Maurice 
terms Casa, Household, Maison-corresponding to the Latin term Familia $^{9}$-cover diverse sectors with distinct functions. Schematically, we can amalgamate these into domestic service, and financial and administrative offices. The sovereign depended on these offices for the needs of daily life and the expression and exercise of his sovereignty, firstly in the palace but also during particular ceremonial or political occasions outside of it. Rank, dignity, duty, and favor defined various hierarchies. Courtiers of the highest rank held offices endowed with particular competences, but the household also included subordinate ranks and offices. As we shall see in our case study, belonging to the lower level of the family entailed particular advantages, but it did not as a rule grant rights of access to the sovereign. Therefore if, as Ronald G. Asch writes, 'the real criterion for membership of the court was access to the ruler, ${ }^{10}$ we cannot simply equate the household and the court. A more careful delineation is necessary, including institutional divisions as well as ranks.

The familia of the pontiff and the Roman Court covered two groups of individuals partly overlapping and partly different. Service to the pope united court and family. Yet while courtiers, who lived in the Palace or carried out missions for their sovereign far away, had access to the person of the pope on certain occasions, even if it might have been limited and regulated, Famuli that carried out humble duties did not enjoy the privilege of being near the pontiff, even though they lived under the same roof. Moreover, in the space in which court and palace coincided, service to the pope could be service to the 'private' person but also to the public person of the sovereign, thus including financial, political, diplomatic and governmental functions.

Aymard and Marzio A. Romani, eds. (Paris 1998) pp. 43-54; José Jurado Sánchez, 'La financiación de la Casa Real española y sus repercusiones sobre la Hacienda y la economía', in: La cour comme institution économique, Aymard and Romani, eds. (Paris 1998) pp. 57-64; José Martínez Millán, ed., La Corte de Carlos V, vol. III. Los servidores de las Casas Reales, vol. IV and V (Madrid 2000); José Martínez Millán and Santiago Fernández Conti, eds., La monarquía de Felipe II: La Casa del Rey II (Madrid 2005).

${ }_{9}^{9}$ In this paper I will use the Latin term familia and the English word family interchangeably in this extended sense. I also will use the term famuli for minor members of the familia. Where I intend family in the more limited and usual sense of kinship by blood or through marriage alliances I shall make this reference explicit.

${ }^{10}$ Ronald G. Asch, 'Introduction: Court and Household from the Fifteenth to the Seventeenth Centuries', in: Princes, Patronage and Nobility: The Court at the Beginning of the Modern Age, Ronald G. Asch and Adolf M. Birke, eds. (London; Oxford 1991) p. 8. 
In his comprehensive study of the papal court of Avignon, Bernard Guillemain considered the papal stay in Avignon to have stabilized the functions and shape of the officiales Sedis apostolicae. This not only comprised administrative posts, but also the service workers linked to the domestic sphere and members of the military orders. ${ }^{11}$ The French historian calculated that 500 to 650 persons followed the pontifical court, of which a more limited number (around 50\%) composed the domestic entourage. ${ }^{12}$ These figures would indicate that the definition of spheres was almost complete at that time. However, as Guillemain often underlines, administrative work and domestic functions remained highly interwoven. They were not always separable and their staffs were interchangeable. ${ }^{13}$

We certainly need to recognize the centrality of the Avignon period as a phase that accelerated the structuring process of the papal court, influenced by the French kingship model and the French nationality of the popes elected in that period, as well as by the court's location on French soil. Nevertheless, even in the 1500s and 1600s it appears to have been uncertain how to define a domestic servant of the pope. However, it is clear that these centuries saw significant changes in the structure of the household of the pope.

In this paper, we will consider two aspects of this transformation process:

I. the organisation of offices into sectors in the late Medieval period;

II. the clarification of privileges and prerogatives in the course of the Modern era.

Our intent is to draw a-necessarily schematic-picture of the household of the pope that shows the many features that this segment of the pontifical court shared with the palace offices of other European sovereigns' courts. It also shows how the specific features became clear and then rigid until the papal court acquired its own distinctive configuration in the course of the Modern age

${ }^{11}$ Bernard Guillemain, La cour pontificale d'Avignon: (1309-1376); Étude d'une société (Paris 1962).

${ }_{12}$ Guillemain, La cour pontificale, p. 722.

${ }_{13}$ Guillemain, La cour pontificale, p. 423. 
Table 1. List of popes $1417-1774$

\begin{tabular}{llll}
\hline Martin V & $(1417-31)$ & Urban VII & $(1590)$ \\
Eugene IV & $(1431-47)$ & Gregory XIV & $(1590-91)$ \\
Nicholas V & $(1447-55)$ & Innocent IX & $(1591)$ \\
Callistus III & $(1455-58)$ & Clement VIII & $(1592-1605)$ \\
Pius II & $(1458-64)$ & Leo XI & $(1605)$ \\
Paul II & $(1464-71)$ & Paul V & $(1605-21)$ \\
Sixtus IV & $(1471-84)$ & Gregory XV & $(1621-23)$ \\
Innocent VIII & $(1484-92)$ & Urban VIII & $(1623-44)$ \\
Alexander VI & $(1492-1503)$ & Innocent X & $(1644-55)$ \\
Pius III & $(1503)$ & Alexander VII & $(1655-67)$ \\
Julius II & $(1503-13)$ & Clement IX & $(1667-69)$ \\
Leo X & $(1513-21)$ & Clement X & $(1670-76)$ \\
Adrian VI & $(1522-23)$ & Innocent XI & $(1676-89)$ \\
Clement VII & $(1523-34)$ & Alexander VIII & $(1689-91)$ \\
Paul III & $(1534-49)$ & Innocent XII & $(1691-1700)$ \\
Julius III & $(1550-55)$ & Clement XI & $(1700-21)$ \\
Marcellus II & $(1555)$ & Innocent XIII & $(1721-24)$ \\
Paul IV & $(1555-59)$ & Benedict XIII & $(1724-30)$ \\
Pius IV & $(1559-65)$ & Clement XII & $(1730-40)$ \\
Pius V & $(1566-72)$ & Benedict XIV & $(1740-58)$ \\
Gregory XIII & $(1572-85)$ & Clement XIII & $(1758-69)$ \\
Sixtus V & $(1585-90)$ & Clement XIV & $(1769-74)$ \\
\hline
\end{tabular}

\section{Organization of the Household}

A document from the beginning of the fifteenth century entitled $D e$ officialibus palatii pontificii enumerates a good 25 categories for officials that served the pope. The Lateran canon Giovan Battista Gattico edited and published this text in the mid-eighteenth century, considering it a significant statement about the customs of the Roman court in earlier eras. ${ }^{14}$

The cubiculari (private chamberlains), intimate domestic servants assigned to the pope's personal service and part of the familia, were divided into cubiculari d'onore (only some of whom were prelates), and cubiculari domestici, (these could be either prelates or laymen). Even as laymen, these servants enjoyed rights of sustenance for themselves

${ }^{14}$ Johannes Baptista Gattico, Acta selecta caeremonialia Sanctae Romane Ecclesiae ex variis Mss. Codicibus et diariis saeculi XV, XVI, XVII. apud haeredes Jo. Laurentii Barbiellini (Rome 1735) p. 263. 
and for two retainers in the Apostolic Palace. In late medieval sources, the office of the cubiculario covered a vast and still not very clearly defined sphere: control of the papal chamber, compilation of a register documenting the order of persons received by the pontiff, care of clothing and valuables. But the office also dealt with letters, petitions and other writings-even secret ones-directed to the pope, and the real possibility of reporting on these to alleviate the work of the pope. The ambiguous nature of these duties contrasts with the more precise definition of other offices that concerned only 'administrative' duties or 'custody' of the person and palace of the sovereign. If in fact the cubicularii could act as referendaries, this did not mean that the pope did not need and have a larger group of official referendaries in the Apostolic Palace for the registration of petitions and letters.

The various specific tasks of court life were each entrusted to a special group of servants. Even the guarding of the doors required specific figures. The hostarii (ushers) were usually honest, trustworthy, and virtuous laymen that slept in the room in front of the papal chamber. The custody of the iron doors was entrusted to two hostiarii chosen from the minor attendants. Six cursori (couriers) served weekly in the Palace as messengers, linking the internal and external space of the court. The scutiferi (shield-bearers, écuyers), an office of honor performed by laymen not living in the Palace, marched in processions carrying the insignia and garments of the pontiff and the court dignitaries behind the Magister palafrenariae who was usually one of the scutiferi, an expert knight in command of an indeterminate number of heralds. Palace organization as a whole pivoted around the Magister Hospitii. He was a layman, a man of authority whose duty-in addition to receiving guests-consisted of keeping watch over everything pertaining to the economic and moral governance of the palace. For example, he oversaw games, prevented brawls, and verified and signed all the coupons of payment concerning the familiares.

The de officialibus palatii pontificii describes in detail the functions of various other positions: the panateria, directed by two presbyters, the buticularia and officium acquae (with three magistri of whom at least two were clerics) saw to the supply and distribution of bread, wines and water, and the floreria (whose holder could be a cleric or a layman) took care of those objects and vestments not falling under the responsibility of the cubicularii. Furthermore, there was the office that supervised the purchase and use of wax as well as the care of the papal 
candelabras (officium cerae). This position was considered very honorable and assigned to an honest and faithful cleric. The office dealing with the custody of the furnishings (de custode vaxellae) was also entrusted to a cleric.

Each of these sectors involved in management of the household also had its own internal hierarchy. The magistri needed to deliver the receipts documenting expenses to the Magister hospitii daily. Even if this administrative-accounting was exclusively their duty, in day-today work they were supported by minor officials. These latter were sometimes clerics and sometimes laymen, like the magister coquinae (secular), the expensor (ecclesiastic), the custos cibariorum (ecclesiastic), the magister operum, the magister aulae and numerous famuli. As at other contemporary courts, the distinction between high and low familia could be blurred within single offices. Except for the easily identifiable major offices, there was still no delineated hierarchy among them.

The offices that strictly concerned the spiritual sphere merit mention. Firstly, the pope's confessore-chosen according to the pontiff's wishes-enjoyed continuous residence in the palace and assisted the pope in the liturgical offices. He had the privilege of riding in the celebration of Corpus Domini immediately following the mule that carried the Holy Sacrament. Secondly, there was the Sacrista. ${ }^{15}$ Thirdly we find the Magister Palatii (the office of doctrinal control distinct from the Magister Hospitii), appointed by the pope from among the Dominican friars. ${ }^{16}$ Then there was the Elemosinarius, who only occasionally resided in the Palace and was a cleric entrusted with assistance of the poor and intercession with the pope on behalf of the prelates, the religious, and ecclesiastical institutions. Finally there was the Magister capellae who governed the service of the papal chapel. Alongsidehim were 12 choristers

15 The Confessore and Sacrista of the pope were a single figure until Sixtus IV; the functions were then separated into two offices and so the family had a confessore that was "part of the apostolic palace." The end of the 1620s settled the right of the order of Servi di Maria to the confessorato of the pontifical conclave. The confessore of the pontifical family could become the confessor of the conclave. See P.A.M. Vicentini, Dei Servi di Maria Memorie storiche (1925). In contrast to the rich bibliography on royal confessori, an up-to-date work on this significant theme is missing.

${ }_{16}$ Giuseppe Catalani, De Magistro Sacri Palatii Apostolici libri duo (Rome 1751). Also refer to P. Innocentius Taurisano, 'Series chronologica Magistrorum Sacri Palatii Apostolici ab anno 1217 ad annum 1916', in: Hierachia Ordinis Praedicatorum (Rome 1916) pp. 111-121. 
and three clerics 'clerici capellae seu caerimoniarum' who only dined in the Apostolic Palace during feasts but received a stipend, the amount of which was noted in the books of the Apostolic Chamber. ${ }^{17}$

Even before the de officialibus palatii pontificii the care and management of the Palace, the physical and spiritual attendance of the person of the pope, and the governance of the curia had been described as specific offices, even if in practice these domains were not sharply differentiated. Moreover the uncertainty about the number of office titleholders is significant: the number of cubicularii, scutiferi, and also hostiarii was not rigidly defined but left to the decision of the pontiff who named them.

Finally, as the formula 'cleric or layman' that in some cases appears alongside the definition of an office demonstrates, the original character of the papal family was not completely clerical. If we take one of the oldest sources, the list of familiares of Nicholas III (1277) published by Galletti, we find numerous dominicelli among the domestic officials distinguished by function and by rank: young noble laymen serving the pope. ${ }^{18}$ In the Medieval period and still at the beginning of the fifteenth century, the household was a fluid social configuration. It was neither static nor completely clerical, even if it tended toward a split between offices of government of the Palace (entrusted to clerics) and offices of honor (entrusted to noble laymen).

Beyond their value for ascertaining the manner of naming offices, ${ }^{19}$ the first nominative lists of papal officials in domestic service inform us of the officials' national identity, reflecting the important change that came about in the papal court after its return to Rome. The Liber officialium of Martin V gives us a diachronic image of the staff of the

17 Etienne Anheim has identified the birth of the office of magister capelle in the first half of the fourteenth century (1336) with management of the chapel, liturgy, and music. At the beginning of the fifteenth century the master of the chapel also received the duty of reading the Bible. In the course of the century the clerics of the chapel alongside him became clerici capelle/clerici caerimoniarum and then became masters of ceremonies. Etienne Anheim, 'Naissance d'un office. Pierre Sintier, premier maître de la chapelle du pape (1336-1350)', in: Jamme and Poncet, Offices et Papauté, pp. 267-301.

${ }^{18}$ Paolo Piccolomini, 'La famiglia di Pio III', Archivio della R. Società Romana di Storia Patria XXVI (1903) pp. 143-164.

19 I have permitted myself to refer to Maria Antonietta Visceglia, 'Denominare e classificare: Familia e familiari del papa nella lunga durata dell'età moderna', in: Armand Jamme and Olivier Poncet, Offices et Papauté, 159-195. 
court. Whether chamber officials or members of the household, those who entered service during the pontificate of the Colonna pope took oaths to the Camerario (the Camerario signed the 'litterae de fructis percipiendis' that allowed the familiares to cash office emoluments) or to the Vice-Camerario. ${ }^{20}$ The cubicularii of the Roman pope Ottone Colonna, whose election put an end to the Western Schism, were highranking prelates, predominantly French, but also German and English. The scutiferi d'honore were also dominicelli of various nationalities.

The courts of Martin V and his successor Eugene IV present an international makeup, ${ }^{21}$ with a strong French presence also in the court of the latter. ${ }^{22}$ But within a few years (in 1460), the domus pontificalis of Pius II (Enea Silvio Piccolomini) had a clearly Italian (in fact Sienese) predominance ${ }^{23}$ and the pontiff's blood relatives were in the key positions of Palace government. Upon the death of the pontiff in August 1464, however, they would be rapidly excluded from management of power. ${ }^{24}$ The nephew of Pius II (Francesco Todeschini-Piccolomini) became pope in September 1503. Although the brevity of his pontificate, which lasted only a month, did not give him the opportunity to make any substantial changes in the family of his predecessor Alexander VI, he brought to the Palace those who had served him as cardinal and those who had belonged to his uncle Pius II's entourage, as well as his blood relatives whose servants were included in the household's ranks. ${ }^{25}$ Pius III's camerarius et depositarius was the Sienese banker

\footnotetext{
${ }^{20}$ Archivio di Stato di Roma, Le Liber officialium de Martin $V$ published by François-Charles Uginet (Rome 1975).

${ }^{21}$ On pope Condulmer see Denys Hay, 'Eugenio IV', Enciclopedia dei Papi, vol. II (Rome 2000) pp. 634-640.

${ }^{22}$ Georges Bourgin, 'La "familia” pontificia sotto Eugenio IV', Archivio della $R$. Società Romana di Storia Patria XXVII (Rome 1904) pp. 203-224.

${ }^{23}$ Gaetano Marini, Degli archiatri pontificii, vol. II (Rome 1784) pp. 152-66; but also in Gaetano Moroni's own voice, see Gaetano Moroni, 'Famiglia Pontificia', in: Dizionario di erudizione storico-ecclesiastica, XXIII, Gaetano Moroni, ed. (Venice 1843), cited pp. 54-57. On Pius II see M. Pellegrini, Enciclopedia dei Papi, vol. II (Rome 2000) cited pp. 663-685, ad vocem. On ceremonial role of Siena during the long stay of the papal court (1460) see: Fabrizio Nevola, 'Ritual geography: Housing the Papal Court of Pius II Piccolomini in Siena (1459-1460)', Renaissance Studies 20, 2 (2006) pp. 202-225, and idem, "'La più gloriosa solemnità che a di de padri nostri giammai fusse veduta": Feste e apparati urbani durante il pontificato di Pio II Piccolomini', in: I luoghi del Sacro, Fabrizio Ricciardelli, ed., Yearbook of Georgetown University at Ville le Balze, Firenze (Firenze 2008) pp. 171-186.

${ }^{24}$ Matteo Sanfilippo, Pio III, Enciclopedia dei papi, vol. III, p. 23.

${ }^{25}$ Piccolomini, "La famiglia di Pio III", cited pp. 143-164.
} 
Giulio Spannocchi, son of Ambrogio Spannocchi who had earned considerable standing in the curia. Ambrogio had already received charge of the Depositaria della Crociata under Callistus III and then became general secretary and treasurer of the city of Rome under Pius II. ${ }^{26}$ The Italianization of the household and the curia, accomplished in the passage from the fifteenth to the sixteenth century, is a complex phenomenon. ${ }^{27}$ It was certainly the result of the change in the characteristics of medieval papal nepotism which lost its original feature as an instrument of military control of the territory. ${ }^{28}$ But it was as well a consequence of the 'pact' that was established between the Italian nobility and urban patricians, on the one hand, and the papacy, on the other. It also reflected the predominance of Italian merchants and bankers in the financial apparatus of the curia. This development was one of the distinctive characteristics of the papacy of the Renaissance and would be consolidated by the Medici popes, the embodiment of a merchant-banker dynasty ascending the papal throne.

But let us return to the familia of Pius III. In total, the Sienese pope had at his service as familiares primae sortis 8 cubicularii (all qualified as domini), 48 camerarii and scutiferi (of which 41 were domini), 8 doctors (one of whom had the title of dominus, the others magistri), and 26 officiales capellae (including 19 cantors). As second-rank members of the familia there were 7 quartermasters and custodians, 34 messengers and heralds, and 56 officiales assigned to the management of the palace. Finally, the third rank of the familia numbered 48 famuli. To this aggregate of 235 people, the 168 famuli of the prelates, cubicularii and scutiferi need to be added. ${ }^{29}$

${ }^{26}$ Recently, the relationship between the Spannocchi and the Roman curia has been reconstructed very analytically. See Ivana Ait, 'Mercanti-banchieri nella città del papa: gli eredi di Ambrogio Spannocchi fra XV e XVI secolo', Archivi e cultura XXVII, nuova serie (Rome 2004) pp. 9-44 (a monograph of Mercanti stranieri a Roma tra '400 e '500).

${ }^{27}$ This turning-point stands out if we consider the nationality of the cardinals created by the popes of the fifteenth century: 7 Italians of the 17 established by Eugene IV, 4 of the 11 by Nicholas V, 4 of 9 by Callistus III, but 8 Italians out of the 12 named cardinals by Pius II, 9 of 12 by Paul II, and 21 of 34 by Sixtus IV (Menniti Ippolito, Il governo dei papi, p. 77).

${ }_{28}$ Sandro Carocci, Il nepotismo nel Medioevo: papi, cardinali e famiglie nobili (Rome 1999) pp. 143-167.

${ }^{29}$ I took these figures from a document of the Apostolic Vatican Library, ms. Vat. Lat. 9027 published by Piccolomini, La famiglia di Pio III, cited pp. 151-164. 
The tripartite division between domini, officiales, and famuli was old. As the list of the familiares of Nicholas III shows and as the representation of the familia later affirmed, the division implies a more articulate distinction than the simple binary opposition between high and low family. It also delineates a triple classification into the intimate sphere, the functional sphere, and the low offices of kitchen, stewardship, and stable. Analogous indications can be obtained from the Rotulus familiae of Leo X, compiled in May 1514. ${ }^{30}$ It lists 28 domestic prelates whose names are preceded by the title reverendus dominus or simply dominus, 64 chamber clerks, 69 cubiculari, 93 scutiferi, 3 people assigned to the chapel ( 1 chaplain and 2 clerics), 4 heralds, 19 custodians (which also included the custodians of the library), almost all had the title of domini. They followed the officiales divided into secreti, a small group that had access to the most exclusive rooms of the Palace, and communes (137).

In its concluding page, the Rotulus reports the comprehensive figures of the familiares: 244 domini, 174 officiales, for a total of 418 individuals to which 265 famuli need to be added. In comparison to the family of Pius III, these figures highlight the growth in the number of the active members of the papal family in all components. This increase certainly relates to the centrality of the papal court in the Renaissance and to the pomp and opulent lifestyle of the period. It was under Leo X, as shrewd observers like the Venetian ambassadors quickly pointed out, that the expenses of the papal House significantly increased compared to past pontificates. ${ }^{31}$

As the biographical profiles of 28 domestic prelates show, the more restricted entourage of Leo X's papal familia comprised prevalently Tuscans. This again demonstrates the very strong connection between the sovereign pontiff's provenance and the composition of his family in the palace, established with the pope's return to the Vatican. But there were also prelates who had initiated their career in different paths, proving themselves in various sectors like the Apostolic Chamber, diplomatic missions, and the army.

The greatest number of private offices were entrusted to those tied by close bonds to the blood family of the reigning pontiff. Each pope

\footnotetext{
${ }^{30}$ Alessandro Ferrajoli, Il ruolo della corte di Leone X (1514-1516) ed. Vincenzo de Caprio (Rome 1984).

${ }_{31}$ Ludwig von Pastor, Storia dei Papi dalla fine del Medio Evo, vol. IV, p. I (Rome 1960) p. 349.
} 
tended to select his own entourage, signaling a discontinuity with his predecessor. However, those who held the offices of the privy chamberlain, the chamber master or others already settled in their curial career would as a rule continue in their positions. The typical structure of the Roman court was always a result of this ongoing precarious dialectic between continuity and discontinuity.

Holding a domestic office implied a relationship of absolute fidelity, but it was neither limited exclusively to the pontiff 's private service nor to specialization in one single duty. The familiaris could be a privy chamberlain from time to time, a financial official, a diplomat, and sometimes even a soldier. At the beginning of the modern era, the career of a courtier was not spelled out in an orderly and consistent way according to a cursus. Often it entailed exhausting and apparently disorderly movement between different offices in the familia and the court, in the Palace and far away from it. Moreover, the practice of some venal offices (generally financial) and membership of certain collegia militum gave access to familiarity through monetary transactions. At the start of the sixteenth century the popes did not begrudge knightly titles and offices of cubicularii and scutiferi. In the bull of 3 September 1515, while war was breaking out in Lombardy (the reference to the war is explicit in the text), Leo $\mathrm{X}$ constituted a college of 60 cubicularii and another of 140 scutiferi. In 1521, he created 41 titles of milites Sancti Petri (the Knights of Saint Peter) placing 26 of them at the disposition of the vice-chancellor. Paul III sold 200 titles of cavaliere dei Santi Pietro e Paolo (the Knights of Saint Peter and Paul 1541), Julius III instituted the college of milites lauretani, Paul IV that of the Cavalieri della Fede (the Knights of Faith) and in 1562 Pius IV created a college of 275 Cavalieri Pii (Pious Knights). The duties of these knights were purely theoretical-following the pontiff to the crusades and general councils-but the prerogatives were concrete. Paul III made it clear that even if they had no precise duties in the Apostolic Palace and even if they did not eat in the 'dining room' (tinello) of the Palace, they needed to be retained as true familiares and continuous dinner companions of the pontiff. In addition, these titles could be accumulated without causing problems of incompatibility with other offices.

But how profitable were these titles of familiarity to the Apostolic Chamber? And what hierarchy was established between them? Two registers compiled in the 1580 s tell us that in 1588 the price of the 
office of a participating cubiculario was 2,082 scudi. ${ }^{32}$ In the same year Francisco Peña, the famous Spanish auditor of the Rota, bought the office of scutifero, vacant because of the death of Aurelio Savignani, for 1,130 scudi. Meanwhile the Bolognese layman Francesco Maria Boschetti bought an analogous office for 1,140 scudi. The knighthood of the Saints Peter and Paul was valued at around 1,300 scudi, that of Saint Peter at 1,035 scudi, the 'lauretano' at 520 scudi, and the 'pious' at 450 scudi. If we think that in the same year Giovan Battista Savelli bought the office of cleric of the Chamber for 40,000 scudi, these are modest figures. But the geographical links of the applicants, the inclusion of laymen and ecclesiastics among them, and the possibility of developing business through the office render the buying of titles a very interesting phenomenon from a social and economic perspective. ${ }^{33}$

The popes of the Renaissance, assigning the title of familiaris to holders of offices and venal titles, created a link between the Palace offices and venality inside the complex machine of papal finance. Among the monarchies of Western Europe, however, this overlap was not unique. An analogous process occurred in France with the offices of the Maison $d u$ Roi. Louis XIV still sold Palace offices, although at the same time the Sun King sought to limit the right of resigning the office in favor of someone else by removing the faculty of resignation except with royal permission. ${ }^{34}$

\section{Prerogatives and Privileges of the Familiares}

In the early modern period, the process of enlarging the ranks of the pontifical familia took place in a fast and disorganized way. It was not always clear to contemporaries themselves which segments of the

32 Archivio Segreto Vaticano (ASV), Instrumenta Miscellanea 4802 (Liber Officiorum 1588), 4803 (Liber Officiorum 1581).

${ }_{33}$ At the Roman court the power to assign the office to a different person (pro admissione resignationis) could be obtained with a modest pecuniary sum: 81 scudi for the office of the participating cubiculario, 54 scudi for that of the knight of Saint Peter, 49 scudi for that of knight of Saints Peter and Paul, and 27 scudi for that of the pious knight (cavaliere pio).

${ }^{34}$ Olivier Chaline, 'The Valois and the Bourbon courts c. 1515-1750', in: John Adamson, The Princely Courts of Europe: Ritual, Politics and Culture under the Ancien Régime 1500-1750 (London 1999) pp. 72-73; Boucher, 'L'évolution de la Maison du Roi', pp. 364-365. 
courtly and curial world fell within the area of familiarity, what profile was required for access, or which honors and privileges derived from being considered a familiaris of the pope.

In the Bulla officii Cubicularium et Scutiferorum Apostolicorum (1515), Leo X established that those holding such offices needed to be generically men of honest living and people of quality, not unaware of or inexperienced in the rites and ceremonies of the Roman church. A doctorate could facilitate the practice of some prerogatives of the office of the cubiculario, but it was by no means necessary. The first Medici pope did limit the number of laymen that could hold this office but nevertheless did not exclude non-ecclesiastical personnel. ${ }^{35}$

More important was the legislative intervention of Paul III (15341549). On 22 December 1534 with the decree de Familiaribus, he put an end to the uncertainties and conflicts by specifying the categories of those that should be considered 'veri familiares pontificis et continui commensales eiusdem. ${ }^{36}$ In other words, these were the cubicularii, referendaries, protonotaries, subdeacons, Rota judges (whose privileges had already been outlined by Clement VII with the decree Convenit aequitati of 2 August 1525), acolytes, secretaries, writers of apostolic letters, heralds and the knights of Saint Peter (provided they served in the palace and carried custodial duties). The privileges of familiaris were quite varied and changed from office to office. They included fiscal exemptions, advantages in property inheritance, the possibility of legitimating bastard children, enjoying special terms of access to benefices and above all, being exempt from ordinary jurisdiction.

If living and serving in the Vatican Palace was indispensable for certain familiares, it was not an unavoidable condition for membership of the pontiff's family, as Paul III again reaffirmed with a new decree dated 18 May 1543. The growing distance between the group of servants actually present in the Palace and those formally considered 'panem habentes' without residing there was a predictable consequence of the increase in Roman offices in the first half of the sixteenth century. It may also be seen in relation to the chaotic and somewhat random growth of the Vatican Palace before the popes moved their

${ }^{35}$ I consulted the bull in the miscellaneous collections of the Biblioteca Apostolica Vaticana (BAV), marked RIV 1333/1.

${ }^{36}$ Aloys Guerra, Pontificiarum Constitutionum in Bullariis magno et romano contentarum epitome, tom. I (Venice 1772) p. 384. 
court to the Quirinal Palace at the turn of the sixteenth and seventeenth centuries. ${ }^{37}$

With the Farnese pope Paul III who from his cardinalship was surrounded by a family of 325 members, the papal household acquired its modern physiognomy. As the household grew larger, the prerogatives of the Master of the pontiff's household were outlined, and the crucial role of the Datary, the link between the household of the pontiff and the financial offices' was confirmed.$^{38}$ In the mid-sixteenth century when the papal family was made up of 421 familiares and 313 famuli of the palace (the figures refer to the pontificate of Paul IV), ${ }^{39}$ a uniform and continuous documentation was initiated that allows us to trace the development of the papal household. The three old categories of domini, officiales and famuli that, as we have seen, were applied until the reign of Leo $\mathrm{X}$, were now abandoned and other criteria were introduced to register the familiares in a Ruolo. ${ }^{40}$

The Ruolo is a document similar to those drawn up for analogous aims by the English monarchy (rolls) and the French monarchy (états). The little book lists all those who received the so-called parte di Palazzo that could be a tutto vitto (in other words bread, wine, oil, biscuit, wax, wood, etc., plus a monetary compensation), a pane e vino (bread and wine compensation) or alternatively a pane solo (bread only compensation). This group notably included the blood relatives of the pontiff-the eccellentissimi signori della Casa with whom the document normally began, including the ladies (mother, sisters, sisters-inlaw, nieces of the pope...). It also comprised members of the papal Secretariat, officials of the Datary, the Chancery, the Chamber, Palace chaplains, judges in the Rota, valets of honor and also ambassadors.

\footnotetext{
${ }^{37}$ On the implications for city life and the curia that was transferred to the Quirinale, see Antonio Menniti Ippolito, I papi al Quirinale. Il sovrano pontefice e la ricerca di una residenza (Rome 2004).

${ }^{38}$ Léon Dorez, La cour du pape Paul III d' après les registres de la Trésorerie secrète, preface by Pierre de Nolhac (Paris 1932) p. 26.

39 The role of the family of Paul IV is discussed in Gaetano Moroni, 'Famiglia Pontificia', in: Dizionario di erudizione storico-ecclesiastica, XXIII, Gaetano Moroni, ed. (Venice 1843) pp. 66-73.

${ }^{40}$ Christoph Weber was the first to call attention to the importance of this document. See 'La corte di Roma nell'Ottocento', in: La corte nella cultura e nella storiografia, Cesare Mozzarelli and Giuseppe Olmi, eds. (Rome 1983) pp. 167-204. There are 432 registers contained in the Ruoli, conserved in the Apostolic Vatican Library. They cover a chronological span from Julius III to Pius IX. On the familia of Pius IV, see Theodor von Sickel, Ein Ruolo di famiglia des Papstes Pius IV Mitteilungen des Instituts für Österreichische Geschichtsforschung, 14 (1893) pp. 537-588.
} 
Those who fell into the category 'Of bread only' included assistant bishops, protonotaries, abbreviators de parco maggiore, consistorial lawyers, referendaries, etc.

This reference to sharing sustenance is only one of the criteria described in the Ruoli. It is significant that the generic term 'domestic prelates,' which in sources from the fifteenth and sixteenth century includes the Master of the Household, the Datarius, the Sacrist, the General Treasurer, etc., would be replaced in the Ruoli by a series of rubrics, each one referring to a bureaucratic department. Thus the Secretariat, originally represented without divisions, was now subdivided into the Segreteria dei Brevi and dei Memoriali. ${ }^{41}$ It became a more composite organ in which the Secretary of State was flanked by a dozen prelates heading the work of the Congregations of the cardinals. ${ }^{42}$ The Datary, a key office for papal finances further augmented under Sixtus V, comprised a total of 30 officials in the 1600s. It arbitrated the delicate matter of pensions, concessions of benefices, curial offices, as well as dispensations regarding consanguineous marriages. The section 'Offitiali di Camera' consisted of 9-10 officials and included a general Treasurer, Commissioner of the Chamber and various 'accountants.'

As has been seen in its rolls, the pontifical family appears to have developed from its original tripartite matrix, which was still heterogeneous, into one divided between a bureaucratic camp that increased in complexity and a sphere of the palace that remained linked to personal service to the pontiff. The two spheres were not integrated into one hierarchy, however, and the Palace offices in the sixteenth and seventeenth centuries still represented around $50 \%$ of the total personnel enjoying the privilege of familiarity. This approximate percentage needs to be clarified and possibly corrected by analytic studies, but it is essentially analogous to Guillemain's proposition for the Avignon period.

A growth in the number of minor offices connected to the demanding services of this increasingly complex machinery is evident in the

${ }^{41}$ This is presented in the Rotulo of the family of Paul IV, published by Moroni after 12 "intimate" prelates put down the names of the six secretaries of the pontiff, among which were Angelo Massarelli and Giovan Francesco Commendone (Moroni, Famiglia Pontificia, cit. p. 67).

${ }_{42}$ Besides the Segreteria dei Brevi, of the Brevi to the Princes, of the Latin Letters, the last role of Clement X (1 June 1676) comprised, in order "Mons. Gio. Battista Spinola de Vescovi e Regolari, Urbano Cerri di Propaganda Fide, Fani di Consulta, Brancacci del Concilio, Gio. Bussi de Bono Regimine" (BAV, Ruoli, vol. 169, 1676, f. 1). 
realm of the household offices. But the dynamics of certain honorific offices regulating access to the person of the pope are no less interesting. The formalization of ceremonial practices and the further elaboration of the criteria of distinction required more personnel to manage an ever more refined etiquette..$^{43}$ For example, the bussolanti (ushers) passed from an average of 6 individuals on the rolls at the end of the 1500 s, to 12 in the second half of the 1600s. They were assigned to service in the more numerous antechambers of the pontifical apartments in the new Quirinal Palace. Dressed in red cloaks with hoods, they were considered equivalent to grooms and extra muros valets (camerieri extra muros). ${ }^{44}$

In addition, we note the increase in Chapel personnel and their distribution into various sections (privy and common chaplains, cantors). The Pontifical Chapel expanded from 14-15 registered units at the end of the $1500 \mathrm{~s},{ }^{45}$ to 60 units (of which half were cantors) at the end of the $1600 \mathrm{~s} \cdot{ }^{46} \mathrm{~A}$ survey of the rolls from the mid-1700s describes an even more crowded Pontifical Chapel: 72 units (46 choristers) in 1741 and 98 units (68 choristers) in $1758 .^{47}$ During the pontificate of Clement XI (1700-1721), the master of the chapel Andrea Adami da Bolsena (who had already been employed as a cantor during the time of Alexander VIII), wrote his Observations for the good regulation of the chorus of the Pontifical Chapel. It shows how recent the tradition of ecclesiastical music-considered the 'invention' of the Spaniard Ambrogio Morales and naturally of P. Luigi Palestrina-was in modern Rome. Moreover, it listed all of the ceremonial occasions, and ordinary and special liturgies in which the pontifical cantors took part, highlighting that the chapel and its cantors gained a more important role in papal ceremonial. ${ }^{48}$

${ }^{43}$ Maria Antonietta Visceglia, 'Etichetta cardinalizia in età barocca', in: Estetica barocca, Sebastian Schütze, ed. (Rome 2004) pp. 263-284.

${ }_{44}$ Brevi notizie sul collegio dei bussolanti pontifici (Venice 1886).

45 This agrees with the number that we obtained from Gattico's above-cited document which refers to the fourteenth and fifteenth centuries.

${ }^{46}$ Visceglia, Denominare, classificare, pp. 190-191.

47 BAV, Ruoli vol. 290 (1741) and vol. 323 (1758).

${ }^{48}$ Andrea da Bolsena Adami, Osservazioni per ben regolare il coro della Cappella Pontificia tanto nelle funzioni ordinarie che straordinarie (Rome 1711). Beyond the celebrations of the liturgical calendar, the cantors of chapel took part in the canonization of the saints, the solemn baptism of Jews, the funeral rites of the cardinals, the coronation ceremonies and funeral rites of the pope. Adami also points out the rivalry over precedence and benefices inside the court between the college of apostolic writers 
The enlargement of the 'offitiali di Libreria' section, with its Latin, Greek, Hebrew, Chaldea and Arabic scriptors and printers (personnel that traditionally formed part of the household), was more restrained. The increase in the 1600s, however, shows how the ambition of the Counter-Reformatory Church to play a universal role could translate into specific and specialized responsibilities. To cite just one example, from among the 14 officials of the library (including two attendants) recorded in the roll of Alexander VII (1659), we find the Prefect Domenico Salvetti, Luca Holstenio as first custodian, Leone Allacci among the Greek scriptors, three Hebrew scriptors and the printer Zenobio Massotti. ${ }^{49}$

In the middle of the eighteenth century there were 15 officials in the library of Benedict XIV, ${ }^{50}$ the number of attendants having evidently stabilized. Among these illustrious names of eighteenth-century scholarship we find the Lebanese and Maronite scholar Giuseppe Simonio Assemani, the principal writer of Arab and Syriac, who was the librarian of the Vatican, and author of the famous Bibliotheca Orientalis (1719-28). ${ }^{51}$ There is also his nephew Stefano Evodio (called in the roll 'reader of Syrian'), the Florentine Giovanni Bottari (librarian of the Vatican, member of the Academy of ecclesiastical history and of the synods), ${ }^{52}$ Father Roberto di Santa Maria, the Pisan Pietro Foggini, ${ }^{53}$ and Giuseppe Garampi, author of a noted unification and inventory project for the archives. ${ }^{54}$

and the college of pontifical cantors (Adami, Osservazioni, p. 11). On the role of sacred music in the ceremonial and on the circulation of ecclesiastical music in Europe of the seventeenth and eighteenth centuries, see Bernard Dompnier, Maîtrises et Chapelles aux XVII et XVIII ${ }^{e}$ siècles. Des institutions musicales au service de Dieu (ClermontFerrand 2003); Stefano Lorenzetti, 'Intersezioni del sacro nell'esperienza musicale tra tardo Medioeo e prima età moderna', in: I luoghi del Sacro, pp. 235-255.

49 BAV, manuscripts chigiani, B I 13, f. 19.

${ }^{50}$ BAV, Ruoli vol. 290 (1741) and vol. 323 (1758).

${ }^{51}$ Giorgio Levi Della Vida, Dizionario biografico degli Italiani (DBI) 4 (Rome 1962) pp. 436-440 (ad vocem).

${ }_{52}$ Giuseppe Pignatelli and Armando Petrucci, DBI 13 (Rome 1971) pp. 407-418 (ad vocem).

${ }_{53}$ Marina Caffiero, DBI 48 (Rome 1997) pp. 449-453 (ad vocem).

${ }^{54}$ On Garampi, see Dries Vanysacker, Cardinal Giuseppe Garampi: (1725-1792): an enlightened ultramontane (Brussels 1995); Marina Caffiero, DBI 52 (Rome 1999), pp. 224-229. On the cultural milieu to which these characters were exposed, see Maria Pia Donato, Accademie romane: una storia sociale, (1671-1824) (Naples 2000); Maria Pia Donato, 'Mecenatismo papale e mecenatismo cardinalizio a Roma tra Sei e 
An important source like the rolls allows us to verify the exchange of offices connected to the most intimate sphere of the court for every pontificate, and can be systematically utilized in working out the names of officials. Even a brief consultation of this documentation clarifies some tendencies of the politics of familiaritas of the Roman pontiffs, which in the Modern age were complex and not always coherent. Between 1500 and 1600, there was a fairly consistent development in the rules and directional lines of the government of the familia, which we can summarize in three points:

\section{Reinforcement of the Area of Privilege}

Gregory XV's bull from 31 March 1621, De cubiculariis pontificiis, ${ }^{55}$ reaffirmed traditional terms of pensions and benefices while it also specified that the cubicularii must be considered comites Sacri Palatii and nobiles romanae Urbis. In other words, being a close familiaris of the pontiff automatically involved access to the Roman nobility. At the beginning of the seventeenth century, privilege was still consistent with the way it had operated in the Renaissance. Members of nobility and patricians sought ecclesiastical careers and service in the Palace in the entourage of the pontiff, but these doubled as a vehicle for social ascendance and ennoblement.

In contrast, in the second half of the seventeenth century, a different dynamic was established when the quality of nobility became indispensable for some offices of the papal family. The turning point can be dated to the papacy of Alexander VII, who required proof of nobility as a precondition for access to even the first step of curial careers and ordered that ministers of the papal chapel had to be noble. ${ }^{56}$ Innocent XII also decreed that only members of families holding the title of the Knights of Malta could be the pontiff's private chamberlains. Urban VIII had enhanced the pontifical Major-domo's office (the ancient Magister hospitii) by ascribing it to his domestic prelates (at times obscure

Settecento e il ruolo della famiglia Corsini', in: Il trionfo sul tempo. Manoscritti illustri dell'Accademia dei Lincei, catalogo della mostra (Modena 2002) pp. 57-64.

${ }^{55}$ Guerra, Pontificiarum Constitutionum, cited p. 383.

${ }^{56}$ Vittore Falaschi, La gerarchia ecclesiastica e la Famiglia pontificia con rami rappresentanti le diverse persone che la compongono, ognuna rivestita dell'abito sagro o civile che gli conviene e l'indicazione del posto che esse occupano nelle cappelle papali (Macerata 1828) p. 86. 
but always faithful) who were then appointed cardinals. At the turn of the eighteenth century, it was regularly held by ecclesiastics of the most exclusive Roman and Italian noble families, ${ }^{57}$ by the pope's blood relatives, or even by his nephew. Typically, in 1713, Pope Albani nominated Fabio Olivieri, his cousin and schoolmate. Pope Rezzonico (Clement XIII) appointed his nephew Giovan Battista who then became cardinal in 1770, and in 1780 Pius VI conferred the position on his nephew Romualdo Braschi Onesti, the son of his sister Giulia. ${ }^{58}$

At the beginning of the eighteenth century, Monsignor Camillo Cybo, holding the office of Major-Domo, staunchly defended its primacy within the pontifical family, always arguing in favor of its privileges. 'The office of Major-domo'-he wrote in one of his many memorials-'is among the most conspicuous of the Court. He is first among the familiares of the Supreme Pontiff and from this post each one usually is promoted to the cardinalate without an example to the contrary. He has total jurisdiction over all familiars described in the pontifical Ruolo. The administration of the Apostolic Palace and the regulation of access depend entirely on him. ${ }^{59}$

The renewed importance of the Major-domo's office after the abolition of nepotism but in a period of unrestrained favoritism (it suffices to think of the famous Coscia case) is connected to a problem of jurisdiction. The reform of the judicial apparatus introduced by Innocent XII suppressed, in fact, the Major-domo's exclusive jurisdiction over the Palace. However according to Cybo, who had ample sectors of the curia behind him, it was an 'error' or misunderstanding that needed to be corrected. ${ }^{60}$ In the practice of the office during the pontificate of Benedict XIII, Cybo took actions to restore the 'economic' and jurisdictional authority of the Major-domo in the Apos-

${ }^{57}$ Filippo Maria Renazzi, Notizie storiche degli antichi vicedomini del Patriarchio lateranense de' Moderni Prefetti del Sagro Palazzo Apostolico, ovvero Maggiordomi Pontifizi (Rome 1784) pp. 139-148. They cover the office between the sixteenth and seventeenth centuries: Ercole Visconti (1688), the three exponents of the Colonna family (Carlo Colonna in 1696, Girolamo in 1732, Marco Antonio in 1758), Ludovico Pico, son of the duke of Mirandola (1712) Nicolò Giudice of the Cellammare prince who would become "protector of the Austrian States" for the Holy See (1716), Camillo Cybo (1725) Francesco Borghese (1729, but only for a few months) Trojano Acquaviva d'Aragona, supporter of the Bourbon party and "plenipotentiary minister and protector of the Kingdoms of Naples and Spain” (1729), and Giovanni Archinto (1770).

58 Renazzi, Notizie storiche, pp. 165-172.

${ }^{59}$ ASV, Fondo Cybo, b.2, f. 7v.

60 ASV, Fondo Cybo, b.2, f. 432v. 
tolic Palaces and in places he considered their dependencies. ${ }^{61} \mathrm{He}$ also attempted to recover control of all the licensed workers: craftsmen and suppliers of the Palace who for minor offences (insults, thefts, brawls) had to be turned over to the Major-domo. ${ }^{62}$ Cybo emerged victorious from the controversy. In September 1728, the pope consented to restore the authority of the Major-domo and to end the dispute provoked by the instructions of Innocent XII.

\section{Limitation of the Expenses of the Papal Family}

Even if the considerable records of the State Archive of Rome's Fondo Camerale still await systematic exploration, we know from the account books of the Major-domo and Secretary Treasurer that it was Sixtus V (1585-1590) who stigmatized his predecessors, above all Gregory XIII, as excessively prodigal in Palace expenditures. The guidelines of prudence and parsimony imparted by Pope Peretti were applied, and the Apostolic Chamber president, banker Olgiati noted in 1589 that 'the expense for the Table of Our Lord is very limited. ${ }^{63}$

An undated document conserved in the Bodleian Library entitled $O f$ the Palace of the Pope and his servants and all the offices and tribunals of Rome, probably goes back to the pontificate of Paul V. ${ }^{64}$ It repeatedly describes the papacy of Gregory XIII as a golden age of the court ('the court bloomed') because of the nobility of courtiers forming the pope's entourage and the level of Palace expenses. Contemporaries came to consider the 1570 s and 1580 s as a peak, almost as a transitory phase between two models of the court. We can understand this transformation as the passage from a court in which 'traditional' nobility was still decisive, to a court which, while maintaining close contacts

${ }^{61}$ For example, this included the Ethiopian church of Saint Stephen of the Moors (f. 248), the Apostolic hospice (f. 394) and the church of Santa Marta where there was a hospital for the family of the pontiff, that "served very few only of low level." Thus, Cybo decided to assign 60 dukes to the hospital on the Tiber Island, sending sick familiares there instead (f. 138v).

62 Interesting lists of the cases : ASV, Fondo Cybo, b.2 ff. 427-447.

${ }^{63}$ G. Ramacciotti, 'Le spese private di Sisto V', Archivi d'Italia e Rassegna Internazionale a.VII (1940) edition excerpt. This article is based on the revised figures of the cameral documentation that the average monthly expenditures for the refectory were about 2,832 scudi monthly (calculation of the second semester) in 1587, 1,438 scudi in 1589. But "in the happy times" of Pope Gregory XIII, they were 4,000 scudi monthly.

${ }^{64}$ Oxford, Bodleian Library, manuscript Selden supra $71 \mathrm{ff} .1 \mathrm{r}-71 \mathrm{v}$. 
with aristocratic lines, was dominated by the figure of the cardinalnephew-Secretary of State.

At the end of the pontificate of Paul V, the total expenses 'for the Palace of Our Lord' were valued at 91,300 scudi. This was almost double the figure (however uncertain) of 48,000 scudi attributed to the time of Julius II, but was analogous to the amount estimated (which retains a degree of uncertainty) for the Renaissance court of Leo X. ${ }^{65}$ Naturally, these figures represent only estimates that need to be substantiated by analytical studies on Palace expenditures and their evolution between the sixteenth and seventeenth centuries. Projects to restructure the spending of the Palace certainly circulated in the second half of the seventeenth century, particularly during the Odescalchi papacy. Innocent XI's broad reform plan included an anti-nepotistic framework, a proposal to diminish the number of cardinals, and the imposition of a strict and severe style in court life. Moroni would write that from the year of his election, Innocent XI 'reformed the table of the Palace and did not admit anyone other than those recommended for their modesty.'66

At the time of Benedict XIII, however, the banquets of the Apostolic Palace were not 'frequent' but 'held with magnificence and dignity. ${ }^{\text {'67 }}$ Among those in which the pontiff participated, Cybo cites the banquets for consecrating bishops and those following the investiture of the Kingdom of Naples which the pope traditionally repeated for each sovereign succession. More frequent were banquets of the Palatine cardinals (in which the pope might decide to participate), Christmas Eve, the evening and the morning of Maundy Thursday and Good Friday, and on the occasion of visits from great princes and the Viceroy of Naples. After listening to the singing of 'virtuosos' and music in the Papal Chapel, the banquets took place in the Hall of Constantine. But from Cybo's report on his activities written in the 1720s, we get the impression that it was not conviviality that cemented the membership of the household in those years. There were other ritual occasions that mobilized the pontifical familia: the distribution of medals, ${ }^{68}$ the gift

65 Pastor, Storia dei papi, IV, p. 349.

${ }_{66}$ Moroni, Famiglia Pontificia, p. 85.

${ }^{67}$ ASV, Fondo Cybo, b.2, f. 25r.

${ }^{68}$ Cybo gives an analytical report on the ceremony for the distribution of the pontifical medals in 1726, some to servants of the Palace. A total of 190 individuals received them (ASV, Fondo Cybo, b.2, ff. 152r-154v). 
of candles on the day of the Candlemas to the cardinals, royal ambassadors, 'ministers' and to all the nobility including noblewomen nuns, ${ }^{69}$ and finally the rite of the Agnus Dei.

This last banquet, held on Holy Saturday, was a ceremony loaded with double symbolic significance, serving as celebration of the mystery of the resurrection and as declaration of obedience to the pope at the same time. It was possibly a transformation of the more ancient rite, already affirmed in the medieval ordines, in which the pope distributed a roasted lamb to his 'messmates'. This was then superimposed upon another Easter rite, the distribution of waxes. ${ }^{70}$

The Agni Dei were in fact wax medals prepared from the remainders of the Easter waxes and pure wax. In the presence of his familia, the pope blessed them with a symbolic baptism, immersing the lambs in holy water to which was added a balsam. The cardinals and the high prelates gathered them up, and the papal chaplains spread them out on white tablecloths. After singing mass on Holy Saturday in the Palace Chapel, the pope would distribute them to the high familia. The rest of the court went to take them from the hands of the pope, 'kissing him on the hand, the knee, the sacred foot,' and receiving a number of agni, varying 'according the diversity of the quality' (that is of the people concerned). ${ }^{71}$ There are many possible readings of this ceremony, but here I would only like to underline the idea of a symbolic banquet, after a baptismal rite, that had as actors the pope and members of his household, a sacralization of communal dining in a court that was gradually becoming more of a church.

\section{Strengthening the Clerical Dimension of the Papal Entourage}

This deals with a long-term phenomenon culminating in the second half of the seventeenth century, the same phase in which the social profile of certain courtly figures became more markedly aristocratic. ${ }^{72}$ Offices of honor also tended to marginalize the lay component of the

\footnotetext{
${ }^{69}$ ASV, Fondo Cybo, b.2, ff. 127r-128v and ff. 142r-144r.

${ }^{70}$ Sergio Bertelli, Il corpo del re: sacralità del potere nell'Europa medievale e moderna (Florence 1990) pp. 120-130.

${ }^{71}$ F. Vincenzo Bonardo, Discorso intorno all'origine, antichità, virtù, benedizioni e cerimonie che usa il Sommo Pontefice in benedire gli Agnus Dei (Rome 1621) pp. 40-55.

${ }_{72}$ On this process, refer to Maria Antonietta Visceglia, 'Figure e luoghi della corte romana', in: Storia di Roma dall'antichità ad oggi. Roma moderna, Giorgio Ciucci, ed. (Rome 2002) pp. 39-78.
} 
Roman Court. For example, among the camerieri d'onore, the number of those of 'cloak and sword' decreased in favor of those 'of the purple dress.' Among the important papal household offices, the secular component retained only the posts of main Quartermaster, (responsible for the buildings, the gardens, and the furnishings of the Palace), the Rider and the Postmaster. The compactly ecclesiastical character of the household of the pope and the Court of Rome, helps to explain why in the eighteenth century there are a growing number of studies on the Palace offices, and especially on their origins.

To reaffirm the privileges of the cubicularii, the Renaissance popes did not hesitate to recall to and even emphasize the imperial derivation of this term, as Leo X had done in the frequently cited bull on cubicularii in 1515. Scholars of the eighteenth century were embarrassed by this profane tie to the classical Roman world. They used their philological skills and qualifications to reconstruct a Christian origin for the offices of the papal household, even if in some cases they had to admit their ancient imperial roots. So when, in 1758, the Benedictine scholar Pietro Luigi Galletti wrote about the 'noblest' office of preserving the pontiff's robes, he did not exclude that it might have been introduced in Rome as an imitation of that of Costantinople. ${ }^{73}$ However in 1776, in a work of a more general nature, dedicated to Pius VI, he appealed to ecclesiastical history and the archives to show how the origin of this office, as well as all offices of the papal Palace in general, was indissolubly connected to the functions of the early church. ${ }^{74}$

According to Galletti the primicero headed the ancient Palace offices of the pope. He was the first of the apostolic notaries in charge of gathering proof of the 'gesta martyrum.' Next was the arcario, who may have also been 'heir of the arcario of the prefect of the praetorium, ${ }^{75}$ but then became the custodian of the early Church's money just as the saccellario, originally the military paymaster, would become the distributor of alms; ${ }^{76}$ the protoscriniario would become the keeper of the writings of the Church, ${ }^{77}$ and the nomenclatore would have the

\footnotetext{
${ }^{73}$ Pietro Luigi Galletti, Del Vestatario della Santa Romana Chiesa discorso (Rome 1758) p. 5.

${ }^{74}$ Pietro Luigi Galletti, Del Primicero della Santa Sede Apostolica e di altri officiali maggiori del Sacro Palagio Lateranense (Rome 1776).

${ }_{75}^{75}$ Galletti, Del Primicero della Santa Sede Apostolica, p. 107.

${ }^{76}$ Galletti, Del Primicero della Santa Sede Apostolica, p. 125.

77 Galletti, Del Primicero della Santa Sede Apostolica, p. 133.
} 
task of calling and inviting guests to the refectory of the pope at the pontifical court.

To sum up this argument, though the offices of the Apostolic Palace coincided with the names of the ancient imperial offices in some cases, as ecclesiastical or papal offices they held totally different responsibilities and functions. This theory was accepted by contemporary authors occupied with the origins of the offices of the papal household. According to the abbot Francesco Antonio Vitale, author of a history of the pontifical treasurers, ${ }^{78}$ the office of arcario may have been the ancestor to that of the chamberlain (camerlengo). Its more modern name was adopted by the papal court from the example of Valois-Anjou sovereigns.

The characterization of the origins of the Major-domo's office appeared even thornier because the name of the office had changed over time: prefect of the Sacred Apostolic Palace, Master of the papal Household, and finally Major-domo by the pontificate of Urban VIII. A heated debate on the question of the pontifical Major-domo's jurisdiction arising between the end of the seventeenth century and the first decades of the eighteenth century entangled the historical and practical levels. Arguing that the office derived from the judex officiorum aulicorum, transformed into the Christian Vicedomino (that is the archdeacon of Rome, head and master of the lower clergy), ${ }^{79}$ legitimized its extensive jurisdictional powers-powers that Benedict XIII wanted to keep in his own hands. In the second half of the eighteenth century, the jurist Filippo Maria Renazzi dedicated a scholarly history on this office to a nephew of the pope, Monsignor Don Romualdo Braschi, Major-domo of Pius VI. In it, he endorsed a theory that the Majordomo originated from the Vicedomino who was destined 'to preside over the pontifical family in the place of the Apostolic Lord, ${ }^{80}$ and to exert jurisdiction over the Palace and the Roman clergy that served in it. According to the Bolognese jurist, it was in the Medieval period, beginning in the twelfth century and continuing during the Avignon interlude that 'they began to create new offices under other names. ${ }^{81}$ With the return of the Holy See to Rome, a process of rearranging the pontifical family 'in the ancient model of domestic discipline'

\footnotetext{
${ }^{78}$ Franciscus Vitale, Memorie istoriche de' Tesorieri generali pontifici dal pontificato di Giovanni XXII a' nostri tempi (Naples 1782).

${ }^{79}$ Renazzi, Notizie storiche, p. 5.

${ }^{80}$ Renazzi, Notizie storiche.

${ }^{81}$ Renazzi, Notizie storiche, p. 4.
} 
was carried out 'little by little,' as far as 'the diversity of times and the changes of customs' would permit. Like many of his contemporaries, he thought this development was still in progress. ${ }^{82}$

The apologetic character of these works and their intent to anchor the history of the Court of Rome exclusively in ecclesiastical history are certainly evident, and yet their reading is neither tiresome nor superficial. Fundamentally, there is a problem and a real question: what was the relationship between an imperial and a papal model of the court? And when we speak of an imperial model, do we mean the Carolingian or the Byzantine?

Without entering into this complex question reaching beyond the scope of my competence, I would like to briefly recall how the first residence of the pope in the Lateran complex in Rome was transformed into the sacrum palatium between the 8th and 9th centuries at the very moment of significant transformation of the papacy's political role in relation to the new-born Carolingian empire. This cultural climate of renovatio imperii, symbolized by the construction of the Palatium Caroli, destined to be the residence of the imperial dignitaries of Charlemagne to the south of the Vatican Basilica, occurred three centuries before Eugene III undertook the construction of the Vatican Palace to its north. ${ }^{83}$

Yet the idea of the sacrum palatium takes us back even further, to the imperial classical roots from which the two pivotal concepts of the Court of Rome grew: familiaritas, and amicitia principis. The eighteenth-century dispute over the relationship between ancient terms and new realities was hardly a mere pedantry of the erudite, but a scholarly and exciting attempt to purge a too courtly and profane genealogy from the papal offices.

${ }^{82}$ Renazzi, Notizie storiche, p. 26.

${ }^{83}$ Maria Teresa Gigliozzi, I palazzi del papa. Architettura e ideologia: Il Duecento. (Rome 2003) pp. 45-61. 